\title{
Transformative Power of Digital Citizenship: Critical Perspectives on Culture, New Media and Pedagogy
}

\begin{abstract}
This paper discusses culture, as a source of conflict than of synergy, how affects the use of new media to build digital citizenships. It also argues that the cultural dimensions of Geert Hofstede, who demonstrates that there are national and regional cultural groupings that affect the behavior of organizations, are very persistent across time. Global online cultures can be described according to the analysis of Geert Hofstede. These ideas can be first based on a large scale into local and national culture differences across subordinates of a multinational digital society. Furthermore, the authors hope that the underlying assumptions and theoretical constructs through the use of Hofstede's cultural dimensions will help digital citizens understand management in an online community, and have both knowledge and empathy with not only the whole local sight but also the global scene. In spite of calls for enhanced collaboration between online societies and different cultures, there is still altercation between digital citizens, groups and nations. On the other hand, they are uncovered to universal dilemmas, troubles and problems which demand mutual understanding for the clarification of these difficulties. Based on the cultural dimensions of Geert Hofstede, building global culture through new media helps digital citizens appreciate the diversities in the way strategists and their supporters think, offering realistic resolutions for digital citizens to help solve conflict between different groups.
\end{abstract}

\section{Introduction}

The use of new media must empower activist communications, which focus on authentic experiences in critical dialogues. Basic socio-cultural assumptions and prejudices can easily generate democratic-egalitarian inequalities. Digital citizenship, therefore, must be inspired to develop culturally responsive, social justice-oriented, critical and creative culture that go beyond power elites' mandates. As mentioned by Burge (2000), there is a need for investigating clearly how to build powerful collaborations among online communities. Also, concentrating on how to negotiate the meaning and usability of flexible online contents is very important for digital citizens in understanding founded on culturally shared interactive online communications. Moreover, online interactions can provide online citizens with a wide range of viewpoints by reverencing individual cultural differences and giving more attentions to diversity issues. Moreover, these citizens can understand how to manage their role tasks, give careful attentions to diverse online community, and understand their important roles to integrate digital communicational technologies in their activities. The paper, therefore, explores how culture affects the use communication technologies and also discusses structure, organization, technology and leadership practices that characterize successful digital citizenship in and across the fields of communication sciences, lifelong learning and social justice activism.

Contemporary theorists and researchers consider digital citizenship to be a situation in which global online users come together to act or decide on issues of mutual interest using shared rules, norms, and structures. The working definition for this paper is that online culture is an interactive process that engages two or more participants who work together to achieve outcomes they could not accomplish independently. Since participants typically work in an organizational context, other 
enabling or obstructing factors may exist. Those are explored through the study of digital citizenship, which is defined for this paper as an open, integrated process (operational, procedural and cultural) that fosters collaboration and encourages participants to expand connections beyond typical boundaries and achieve innovative outcomes. In this paper, the authors highlight the electronic aspects, applications and issues surrounding online culture to discuss and analyze cultural effects on the use new media. The focus of this paper is to be on the strategic, and critical as well as cross-cultural required to collaborate and achieve global interactions in the age of a digitally connected $21^{\text {st }}$ century global society.

\section{Purpose}

To fortify digital citizens' performances, there must be careful efforts to not only cultural reform but also support these online learners with ready access to information that provides them with improving equal access opportunity to the system (Hodson, 1999; Powazek, 2002). Because of the diverse nature of the world, therefore, new media should vary across a number of dimensions if they are to be effective. A good online strategy for being digital citizens should take into account the facts that different troubles demand different solutions. Diversity of problems, which makes difficult the design of knowledge networks and their cultures, also complicates the design of new media. It is essence of culture that it is communicated and acquired as well as social inheritance. It is quite clear that culture is inseparable from new media since new media in the widest sense of the world refers to not only new technologies and communication methods in the context of their effects on the established mainstream media; but also a group of relatively recent mass media based on new information technology including all forms of computer-enhanced communications. Hence, this rapidly changing online world often challenges digital citizens to communicate across many cultural boundaries and borders, and also reflects diverse perspectives on communication between the world's cultures. In this context, the main purpose of this paper is to present responses to the following questions: How does culture affect the use of new media to

1. cover the challenges with fairness, expectations, respect, and communications inspired by the arts and critical dialogues to share power and cultures, and also help digital citizens deeply engage in lifelong learning activities that examine the dynamics of democratic changes in online community by improving reflective practices for greater impact;

2. engage digital citizens in critical civic responsibilities, dynamic academic curriculums and powerful social actions to understand the possibilities and potentials of democratic decision-making and dialogic leadership that develop culturally responsive and integrated social justice communication plans including anarchist change models that promote inclusive online communications;

3. provide unique and diverse perspectives with their own methodological strengths and weaknesses to obtain genuine equal opportunities and democratic participations in building online knowledge networks not characterized by power, dominance, hierarchy and competition, discuss the philosophical foundations and backgrounds of concepts, insights and skills needed to accelerate democratic transformations, and challenge power elite mandates via points of tension, and 
4. promote critical communication activities for digital citizen engagements in democratic decision-making to promote authentic and high quality lifelong learning experiences by reconciling the pressures for diversity and difference with engaging in anti-racist, social activism and alternative communication practices through the arts and critical dialogues that inform new models and approaches to diversity online communications.

Besides, the mission of this paper is to integrate collective acts democratically to the fast developing philosophical, historical, political, and socio-culture backgrounds and contexts of new media that can bring together a community of people committed to liberatory communication and social justice. Therefore, as mentioned by Preece, Rogers and Sharp (2002), digital citizenship must be designed to represent a range of real-life experiences in their community works and critical praxis, including theorists, theater workers, artists and others committed to transformative pedagogy and social equity. Based on these concerns and also approaches, the researcher also develops a frameworks that can help digital citizens to involve in online culture that are constitutive of contemporary challenges and tensions in the role of technology for sustainable development around the world. In short, online culture can be designed related to the potentials and impacts of diverse online communications that provide background knowledge needed to understand the communication processes related to democratic and multicultural elicit issues, and the international dimensions of the challenges faced by education. As emphasized by Culwin, MacLeod and Lancaster (2001), online cultures can be egalitarian and liberating only when it prepares digital citizens for fully democratic participation in social life and equal claim o the fruits of economic activity. This paper, therefore, builds a theoretical framework that develops strong the engagements for digital citizenships to their shared responsibilities. Also, the needs and expectations of these citizens can bring about democratic decision-making for dialogic citizenships play an important role in affecting deep community change. These are crucial concerns to examine their multifaceted responsibilities in building online culture.

\section{Theoretical Framework}

Bringing theory to practice, the authors apply the cultural dimensions of Geert Hofstede that culture affects the use of new media. In favor of Hofstede's dimensions of power distance, individualism, gender bias, uncertainty avoidance and time orientation, the four communication components of new media are discusses - arts and critical dialogues, communication plans, critical communication progress and alternative communication practices. The approaches of cultural analysis and new media component analysis bring to attention the complex decisions required in the construction of meaningful websites designed to cross borders. Geert Hofstede's culture theory (Hofstede, Pedersen \& Hofstede, 2002) establishes five dimensions of culture. Whether this theory is appropriate as an analytical framework for the following research became another focus for this investigation. Hofstede demonstrated that there are national and regional cultural groupings that affect the behavior of organizations, and that are very persistent across time. As mentioned by Mamadouh (1997), culture is an attractive concept to portray the specific preferences regarding new media in different online communities. Not only is it a vague concept because of the perplexity between patterns of individual values and collective culture, but also the arguable separation between orientations and practices. 
There are dedicated a number of researches, which focus on the discerning topics and critics of culture and new media (Berg, 2000; Burniske and Monke, 2001; Huerta, Ryan, Igbaria, 2003; Kendall, 2003; Rosenberg, 2001; Salmon, 2000; Stephenson, 2001), such as, providing frameworks for planning, delivering and evaluating online contents, discussing the different dimensions and strategies of e-learning, providing design strategies for building online communities, and focusing Learning Management Systems to deliver online contents, etc. However, we need more specific studies, which concentrate on the theoretical and empirical issues about how to design and maintain online communications successfully; because online providers must help digital citizens to think critically about real-world problems by using multiple ways, collaborate with each other successfully, and respect others' ideas and values in online milieus. Therefore, as suggested by Burniske and Monke (2001) and Howell, William and Lindsay (2003), online providers must be reformminded individuals. In these circumstances, online communications must construct multicultural online learning contexts dealing with real-world problems, and have flexible contents. Therefore, digital citizens can engage in their own learning to accomplish course tasks, improve their critical thinking skills, and share their feelings and ideas successfully. This critical approach encourages online providers and stakeholders to construct both meaningful and multicultural milieus for everyone. Therefore, they have to rethink about planning multicultural communication activities and gaining knowledge from global resources. On the other hand, over the past few years, lifelong learning has been explosively popular with the world, which is dealing with the enormous growth of the electronic communication environments. Therefore, interactions among digital citizenships must promote collaborative partnership environments for lifelong learning. This foundation can enable them to understand problems and perspectives from the real world that these critical communicational activities can help these people focus on preparing real-life related problems in their online societies. In this case, building online culture via new media becomes not only a dynamic social and cultural activity as well as a goal-oriented process. Therefore, digital citizens must work together to embrace this critical perspective to describe and analyze their lifelong learning projects. By examining real-life experiences of their partnerships in pedagogical situations, these citizens should know how to implement collective action for moving beyond transmission model for social justice issues and implications for critical pedagogy.

\section{Culture and the Use of New Media}

Not only do online communications help digital citizens facilitate multicultural ideals of inclusive, interactive, and collaborative activities, but also help these people perceive the world better, think critically and perform decisively. The milieus in online learning around the world manifest a novel outlook that values the diverse qualities and capabilities of global knowledge. Time and location independent learning opportunities are a consequence of the philosophy of dynamic and democratic online education. Therefore, new media is becoming a powerful tool, which constructs flexible contents to generate cogent online possibilities related to multicultural contexts. In order to build the appropriate flexible online contents for digital citizens, professionals and community must consider how they can demystify the principles of sharing knowledge online. New communication technologies impact on delivering multicultural knowledge networks. These networks with interactive communication models and approaches have the enormous potential to promote the issues of 
justice, equity and human rights, and enhancing values and ethics for building interactive communication milieus. However, to make the philosophy of distance education worthwhile must cover these issues given below (Bolliger \& Martindale, 2004; Huerta, Ryan, and Igbaria, 2003; Fisher, Wright, 2001; Kyrish, 2004; Nieto, 1996; Porter, 2004):

1. enhancing digital citizen academic achievements to link powerfully the theory, policy and practice of actual democratic and multicultural communications,

2. providing these people with an apprenticeships model to make sense of their educational and personal experiences,

3. serving these citizens equitable and high-quality communication opportunities to encourage interactive collaborations among them to attain a wide perspective,

4. taking account of the knowledge, experience, needs, interests and aspirations of each person, regardless of their social, cultural, economical and political backgrounds,

5. clarifying the relationships among academic, technological and multicultural knowledge to benefit from personal experiences,

6. generating opportunities for digital citizens to become critical thinkers and also productive members of a democratic online society,

7. encouraging their attempts to rethink and reconstruct their ideas, views, needs, expectations, beliefs and attitudes toward cultural pluralism, and

8. exposing these people to different perspectives through a variety of philosophical strategies.

To better understand and construct the societies via new media, it is crucial to focus on the management strategies of global knowledge networks among societies. These strategies help digital citizens interact wisely with all knowledge sources from around the world and around the clock being aware of providing multicultural environments. To transfer gradually more overwhelming amount of knowledge among digital citizens, therefore, new media deal with the quandaries of digital diversity shaped by emerging communication technologies to build knowledge-based network societies. More new media have gradually involved in communication change process. Digital citizens have to deal with the challenge to accomplish access and equity issues by integrating digital technologies with increasing knowledge qualities and quantities. Moreover, they have to appreciate the various learning needs and expectations of diverse groups around the globe. Also, as discussed by Huerta, Ryan, and Igbaria (2003), these people must progress generative enlightenments to build interactive online communications with multicultural e-content standards based on the philosophy of democratic education.

\section{Arts and Critical Dialogues}

Building global online culture via new media should focus on how radical changes are fostered by democratic rules and principles. As mentioned by Brosio (1994), a democratic online society can long survive if it does not allow elite powers and dominant groups to dictate the flow of information to generate the butterfly effect that was first described by Lorenz at the December 1972 meeting of the American Association for the Advancement of Science in Washington, D.C., brightly illustrates the essential idea of chaos theory. To be a digital citizen in the digital age means to make diverse choices. New media are only as successful as its empowerment of the 
digital citizens. In the complex times ahead, digital citizens can share power and culture in various democratic ways by questioning what new media assume roles, what the pros and cons are effective new media, and when new media make policy choices what norms and values are reaffirmed or threatened to the digital citizens. The very survival of democracy may, in fact, depend upon this one thing. We now hear much about the speed of change and the way that new technologies will transform the economic and social landscape of the online world in a few short decades.

To make the philosophy of global culture worthwhile, new media should cover the organizational features of online knowledge networks that affect the process and outcomes of planned change cultural activities among digital citizens (Bates, 2000; Burke \& Chidambaram, 1999; Chua \& Ngee 2001; Fabos \& Young, 1999; May, 1999; Neo, 2005; Resta, 2002; Schrum \& Benson, 2002; Stevens-Long \& Crowell, 2002):

1. What skills are required to construct and support a milieu that focuses on working collaboratively with colleagues and global partners in global online culture through new media that to engage learners in projects designed to be realistic, intriguing and relevant to real life experiences?

2. What advantages do digital citizens to promote excellence through continuous process improvement and the creative pursuit of new ideas and systems in global online culture through new media to model how theory translate into practice on complex decision making process to encourage digital citizens' independence in thinking critically in the global context?

3. What does it mean to plan, communicate, motivate, manage, and lead effectively in professional development and lifelong learning endeavors in global online culture through new media to propose situate communications in an authentic context by engaging digital citizens think deeply to encourage engage to take ownership and responsibility for their decision making process when communicating online?

Building online global culture must be based on a philosophical, theoretical and political orientation that emphasizes the relationships between power and privilege. To develop positive attitudes toward others' diverse backgrounds, first of all, digital citizens must accept that all people have equal rights. In addition, to accept people from the world, they must engage online participants in collaborative e-activities with others. New media must give carefully attentions on the self-esteem progress of the digital citizens. Without strong bases of self-confidence (Sheets-Hernandez, 2004), they cannot be successful online participants to value themselves, respect individual freedoms and take risk in making errors. In addition, as highlighted by Spring (1999) and Torres (1998), new media must build various interaction milieus to match the social needs of online participants who have the diverse race, gender, ethnicity, religious, language, size, cultural and social backgrounds with or without disabilities.

\section{Communication Plans}

Not only is communication plans the familiarities and awareness of facts, truths and/or information gained through experience, learning and self-contemplation, but also it means the confident understanding of a subject, potentially with the ability to utilize it for a specific purpose. Therefore, communication plans can be built up from collective interactions with the world, and is organized and stored in each individual's mind (Scardamalia, 2003). The construction of communication plans, however, requires more than collecting, acquiring and transmitting large amounts of 
information, data and experience. Knowledge emerges from the interactions of body, mind and soul by emerging from understanding the social word. Besides, as critically pointed out by Beaudoin (2003), communication plans that membership in the community accords to rights suggests that important responsibilities tie the individual self to collective due to remarkable advances in computing and communication areas. The cutting-edge technologies can build powerful multicultural networks to share and exchange knowledge for the prosperity and well-being of its members by using an electronic network to send and receive information across any locations, devices and business services. New media, therefore, can generate new forms and tools of gathering data, manipulating and storing knowledge, transforming information, and working together over distance and time that build online societies efficiently. Building online societies encourages digital citizens to effectively transfer their knowledge to the new contexts of educational and social justice. As a result, all these lifelong learners can improve their complex critical thinking skills to construct, produce or demonstrate their knowledge. Besides, they can discover constructivist rubrics to assess lifelong criteria and promote partnerships among diverse people. Building online knowledge societies must be the most important goals of building global culture in the online world. Although the existing milieu for building global culture concentrates on the integration of knowledge from diverse sources and domains across space and time that is forced by not only ambiguity but also continuous radical changes, new media can provide the infrastructure to send bits anywhere, anytime in mass quantities-radical connectivity. As strongly highlighted by Moore \& Kearsley (2005), the exploration of communication plans begin with a series of diverse concerns:

1. introduce the philosophy that underlies the concept of global culture to provide digital citizens with successful activities and agreements for online communities by working together without space and time obstacles,

2. provide a general orientation and overview of global culture to recognize the ethical, legal, and social implications of new developments in online communities,

3. reason about the analysis of global culture via appropriate data processes and integration of knowledge from diverse sources from the world,

4. provide multicultural insights into cultural differences to accomplish innovative levels of interactivity by increasing in-depth concerns among people and communities, and

5. demonstrate the relationships and functional interactive communications across disciplines, languages and cultures.

Digital citizens, therefore, can advance their extensive productivity, social opportunities and intellectual potentials through more focused advance strategies. More specifically, online global culture can represent more well-planned and selective ways of looking for flexibility, value and beneficial arrangements within the global cultural, political and economical issues associated with the emerging technologies. As pointed out by McChesney (1999) and Kendall (2003), online global culture must generate the collective commons committed to expanding the variety of creative works available for their all members to legally build upon and share.

\section{Critical Communication Progress}

Critical progress should explore how a community of digital citizens committed to social justice generates, negotiate and make sense of their social experiences in the 
online world, and also represent a range of experience in their community work and critical praxis, as theorists, educators, theater workers, artists and others committed to transformative pedagogy and social equity. In this context, online communications are not only activist processes but also complex decision making progressions in culturally diverse digital milieus (Porter, 2004). Global online culture through critical process should expose on online critical dialogues that deepen our awareness of innate social and cultural biases, stereotypes and prejudices, and challenges the social construction of dominant elite and social inequalities in online collective activities. Therefore, digital citizens must be educational activists from Universities, Community Colleges, K-12 Schools and the wider community. Also, they must focus on critical educultural communication approaches for global culture. Moreover, they have to develop culturally responsive, social justice-oriented, critical and creative communication plans that go beyond elite power mandates. In this context, critical progress ties digital citizens' own well-examined experiences of race, racism, and whiteness to practical and essential concerns with social justice and the dismantling of racism and its supremacy within the online milieus. New media, therefore, can present responses to the following questions:

1. Have developed practical cultural responses to the impact of race and diversity on digital citizens' consciousness and practices, and on the associated online communicational experiences that can inform new models and approaches to diversity communication?

2. Are interested in developing critical and creative pedagogical responses that interrupt current one-size-fits-all educational mandates and the reproduction of power and privilege in and beyond the traditional culture that promote inclusive communication?

3. Provide diverse perspectives that acknowledge digital citizens own multiple and sometimes contradictory race, ethnic, class, gender, sexual, and ability experiences that points of tension and propel progress?

By respecting individual differences, online communities with the ideas of multicultural strategies increase the quality of new media successfully. Since new media are social and cultural experiences, racial differences are irrelevant, intelligence is multidimensional and distributed. Besides, these networks must be equipped with not only high-tech systems but also new visions of global online societies for supporting their citizens to discover new plans for political resistance and power elites. In this context, global online culture through critical process can make their points of agreement and disagreement explicit that order their citizens' perspective of the future by being aware of diverse cultural backgrounds determined by social movements. Stating the existence of new and potential interesting subjects of interest for collective actions, on the other hand, does not tend to underestimate changes in the short run confounded by the vast, apparently endless obviousness of new unpredictable issues. To promote diversity in online societies including various interest groups to use multicultural resources for egalitarian transmissions makes fundamental changes in online citizens' main concerns according to the struggles between capitalist hegemony and its democratic challengers; and realizes the existence of new, potentially interesting subjects of interest for collective actions that power can be shared among diverse populations to shape the online public policy by involving efforts from a wide range of challenging social groups. Distinguishing novel and emerging communicational relationships formulated by the large shared interests of new media that can structure according the power of whole communities. 


\section{Alternative Communication Practices}

Alternative communication practices have great significance to emerge in sharing knowledge online, and having profound effects on critical thinking (Abbey, 2000). Unlike knowledge sharing in traditional milieus, online knowledge sharing to build powerful networks is relatively flexible, open and egalitarian that has instituted fundamentals changes in collective communication actions (Moore \& Tait, 2002). These reform movements progressively support digital citizens and society partnerships based on the sound principles of communication theories. These improvements, therefore, must be concerned with the development of the whole collaborative interactions within digital multicultural knowledge-based societies. Global online culture, therefore, has a radical potential to deliver global knowledge by promoting the democratic principles of social justice around the world. These location independent communication opportunities become a consequence of the philosophy of dynamic and democratic lifelong learning. Therefore, new media are powerful means to generate logical online possibilities and flexible contents. In order to build appropriate flexible lifelong contents for digital citizens, new media must focus on methods, techniques and principles as well as barriers to share and exchange knowledge in online communications. According to the philosophy of lifelong learning, alternative communication practices can be capable of designing and maintaining effective culture to provide these citizens with flexible collaboration contents. Besides, global culture can be able to help them become engaged citizens, informed individuals and dynamic members in their online society to improve their communication styles and abilities with each other. However, there are limited researches and theoretical articles about alternative communication practices to assist lifelong learning with real-life experiences. Therefore, culture can bring a new ground by addressing key questions about digital citizens' communication styles and abilities, and real-life experiences. Based on these concerns discussed above, the key inquiries in online communities must be:

1. What extents do digital citizens' skills continue to improve their communication styles and abilities via new media?

2. What kind of online authentic experiences are associated with developing communication styles and abilities via new media?

3. What are digital citizens' patterns of participation in communication styles and abilities via new media?

4. What are the impacts of communication styles and abilities via new?

In this case, online culture must be an active process to obtain, evaluate and produce knowledge. Therefore, individuals can become active participants in their knowledge constructions rather than passive receptacles. In this constructivist milieu, digital citizens can work on complex global projects via new media. Besides, these projects must be followed from a theory of communication to become meaningful and understandable. Lifelong learning environments with high levels of communication can be valuable tools to enhance interactive and collaborative communications through new media around the world. Therefore, culture provides invaluable information about the changing and evolving needs and benefits of lifelong learners. Furthermore, as underlined by Rosenberg, (2001), Sheets, (2005), and Scardamalia (2003), culture addresses the specific communication problems. Distance communication designers, policymakers, and scholars can concern a structured way to improve digital citizens' communication styles and abilities to look at practices and learn from evidences with reducing reliance on trial and error. Finally, culture helps 
online individuals rethink traditional communications and be aware of their communicational strengths and limitations in online societies.

\section{The Cultural Dimensions of Geert Hofstede, Culture and New Media}

Communicational reforms have great significance to emerge in sharing knowledge online, and having reflective effects on building global online culture (Picciano, 2002). Although culture is widely recognised as a critical organisational resource irrespective of new media, powerful networks can maximise the value of this resource without adequate understanding of how to leverage and share knowledge throughout the online society (Stephenson, 2004). These reform movements progressively support digital citizens based on the sound principles of communication theories. These improvements, therefore, must be concerned with the development of the whole collaborative interactions within digital multicultural knowledge-based societies. These knowledge networks have radical potentials to deliver global knowledge by promoting the democratic principles of social justice around the world. The most essential elements of culture are the social, political, economical, institutional, technological and educational backgrounds of online societies. Regardless of the developments and improvements in the digital world over the decade, on the other hand, there are still many challenges and risks to establish, deliver and implement online contents via new media. Launching and maintaining new media need not only money and other funds, but also well-educated human resources for online support services. In this context, digital citizens can focus on the complex communication problems with their unique answers of their societies, and help their colleagues and stakeholders in community build not only progressive but also integrated global culture together. Moreover, these people can drive attentions on the principles, ethics and pitfalls of sharing and exchanging knowledge to work on critical communication policies based on the diverse opportunities of their society.

Flexible contents are an approach to new media which offer digital citizens choice in what to communicate, how it is interacted and collaborated, and when and where learning happens. Moreover, these contents provide a dialogical support for the design and development of effective new media designs for online community to share knowledge in their place and pace. To increase flexibility in new media, digital citizens seek to increase the choice of professionals and community in one or more of these aspects of critical communication activities. These actions refer to both a multicultural philosophy and a set of techniques for flexible delivery, access and communication. To emphasize global online cultures, digital citizens' needs and interests, thereby provide new media with the diverse potentials to focus on the development of an enthusiasm for participation in an online community. In addition, the place of multicultural content designs for new media can be examined in relation to the face-to-face, distance and open models of communications. The processes involved in the design, development, delivery, evaluation, improvement and management of new media can be explored to take the multicultural chances to develop the higher-level thinking skills needed to share knowledge online. To provide real-life examples for digital citizens constructs flexible communication contents by enhancing the network-based technologies. Developing a critical understanding shows the needs, expectations and strengths of digital citizens as they interact with global online culture regarding their academic and social progress in elearning milieus. In this context, also, global online culture can support how new media can fit into digital societies. The availability of these cutting-edge technologies is crucial for 
not only digital citizens but also scholars, professionals and policymakers to make decisions for enhancing multicultural interactions about how they can provide flexible communication settings for diverse people. Table 1 summarizes briefly Hofstede's cultural dimensions and new media dynamics. The table has five dimensions horizontally (power distance, individualism, masculinity, uncertainty avoidance and long term orientation regarding time), and four dynamics vertically (arts and critical dialogues, communication plans, critical progress, alternative communication practices).

\begin{tabular}{|c|c|c|c|c|c|c|}
\hline \multicolumn{7}{|c|}{ BEING DIGITAL CITIZENS } \\
\hline \multicolumn{2}{|c|}{$\begin{array}{l}\text { Hofstede's } \\
\text { CULTURAL } \\
\text { DIMENSIONS }\end{array}$} & $\begin{array}{c}\text { Power Distance } \\
\text { (PD) }\end{array}$ & $\begin{array}{l}\text { Individualism } \\
\text { (IDV) }\end{array}$ & $\begin{array}{l}\text { Masculinity vs } \\
\text { Femininity } \\
\text { (MAS) }\end{array}$ & $\begin{array}{c}\text { Uncertainty } \\
\text { Avoidance (UA) }\end{array}$ & $\begin{array}{l}\text { Long-Term } \\
\text { Orientation } \\
\text { (LTO) }\end{array}$ \\
\hline \multirow{4}{*}{ 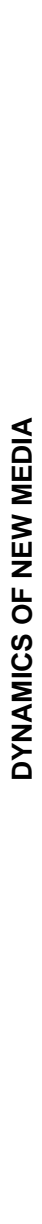 } & 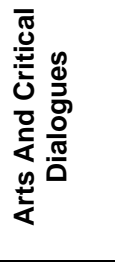 & $\begin{array}{l}\text { less powerful } \\
\text { members expect } \\
\text { and accept } \\
\text { unequal power } \\
\text { distribution } \\
\text { within a culture }\end{array}$ & $\begin{array}{l}\text { the degree to } \\
\text { which individuals } \\
\text { are integrated } \\
\text { into groups }\end{array}$ & $\begin{array}{l}\text { the degree to } \\
\text { which gender } \\
\text { roles are distinct } \\
\text { and adhered to } \\
\text { within a society }\end{array}$ & $\begin{array}{l}\text { the extent to } \\
\text { which the } \\
\text { members of a } \\
\text { society feel } \\
\text { threatened by } \\
\text { uncertain and } \\
\text { unknown } \\
\text { situations }\end{array}$ & $\begin{array}{l}\text { the extent to } \\
\text { which long- } \\
\text { termism or } \\
\text { short- termism } \\
\text { appears to be } \\
\text { the dominant } \\
\text { approach }\end{array}$ \\
\hline & 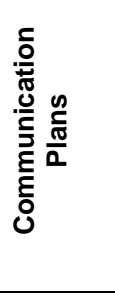 & $\begin{array}{l}\text { have centralized } \\
\text { political power } \\
\text { and exhibit tall } \\
\text { hierarchies in } \\
\text { organizations } \\
\text { with large } \\
\text { differences in } \\
\text { salary and } \\
\text { status }\end{array}$ & $\begin{array}{l}\text { societies in } \\
\text { which the ties } \\
\text { between } \\
\text { individuals are } \\
\text { loose }\end{array}$ & $\begin{array}{l}\text { gender roles } \\
\text { overlap, with } \\
\text { both men and } \\
\text { women valuing } \\
\text { 'feminine' } \\
\text { qualities }\end{array}$ & $\begin{array}{l}\text { low uncertainty } \\
\text { avoidance } \\
\text { cultures, where } \\
\text { precision and } \\
\text { punctuality are } \\
\text { less important }\end{array}$ & $\begin{array}{l}\text { Long-termism } \\
\text { stressing } \\
\text { perseverance } \\
\text { and being } \\
\text { sparing with } \\
\text { resources }\end{array}$ \\
\hline & 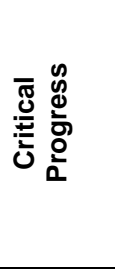 & $\begin{array}{l}\text { disappear } \\
\text { quickly from } \\
\text { traditional } \\
\text { cultures, even } \\
\text { with powerful } \\
\text { global } \\
\text { telecommunicati } \\
\text { on systems }\end{array}$ & $\begin{array}{l}\text { societies in } \\
\text { which digital } \\
\text { citizens from } \\
\text { birth onwards } \\
\text { are integrated } \\
\text { into strong, } \\
\text { cohesive in- } \\
\text { groups }\end{array}$ & $\begin{array}{l}\text { a preference for } \\
\text { being busy and } \\
\text { being precise } \\
\text { and punctual }\end{array}$ & $\begin{array}{l}\text { High uncertainty } \\
\text { avoidance } \\
\text { scores mean } \\
\text { that there is a } \\
\text { fear of } \\
\text { ambiguous } \\
\text { situations }\end{array}$ & $\begin{array}{l}\text { short-termism } \\
\text { involving a } \\
\text { greater } \\
\text { emphasis on } \\
\text { quick results }\end{array}$ \\
\hline & 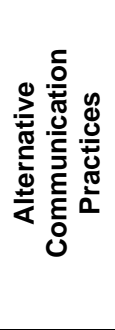 & $\begin{array}{l}\text { view } \\
\text { subordinates } \\
\text { and supervisors } \\
\text { as closer } \\
\text { together and } \\
\text { more } \\
\text { interchangeable, } \\
\text { with flatter } \\
\text { hierarchies in } \\
\text { organizations }\end{array}$ & $\begin{array}{l}\text { digital citizens in } \\
\text { exchange for } \\
\text { unquestioning } \\
\text { loyalty. }\end{array}$ & $\begin{array}{l}\text { global online } \\
\text { cultures at the } \\
\text { levels of } \\
\text { symbols, heroes } \\
\text { and rituals, } \\
\text { together labeled } \\
\text { practices }\end{array}$ & $\begin{array}{l}\text { all sorts of } \\
\text { problems for } \\
\text { digital citizens in } \\
\text { multinational } \\
\text { societies in other } \\
\text { countries }\end{array}$ & $\begin{array}{l}\text { differences } \\
\text { between } \\
\text { national cultures } \\
\text { based in deep- } \\
\text { rooted values, } \\
\text { which are largely } \\
\text { implicit rather } \\
\text { than openly } \\
\text { acknowledged }\end{array}$ \\
\hline
\end{tabular}

Table 1. Being Digital Citizens

As focused on the table, the multifaceted responsibilities of new media in supporting digital community actively engaging in building their communities should investigate how digital citizens, theoretically and practically, recreate more dialogical and democratic forms of pedagogy and community engagements to focus on conscious and unconscious barriers and possibilities of building global culture (Scardamalia, 2003). New media, in this context, must explore the main characteristics of being digital citizens, and discuss how to online culture promotes online communications to model how theory translate into practice, and integrate authentic partnerships by clearly stating the pedagogical guidelines to build online societies. As the $21 \mathrm{st}$ century begins, online societies are undergoing many profound changes associated 
with global social, societal, political and economic forces. Global online culture, therefore, plays a leadership role in the global reflection on communication reform. Although it provides a platform for critical dialogues on how best to adapt education systems to the emergence of knowledge societies in generating and delivering multicultural knowledge, it is often less responsive than its diverse challenges and obstacles of how to utilize new media in activist reactions to greater competency and assurance within its complex reality and comparative perspective. Investigating in various ways to both a prospered variety of inquiry and a deepen focus on the meaning of quality in culture empowers online communities. To fortify these organization performances, there must be careful efforts to reform communication system, and support knowledge management to provide stakeholders with improving equal access opportunity to the system (Moore \& Kearsley, 2005). Quality in these online communities is a multidimensional concept. To accomplish in multifaceted efforts to improve online communication policy and practice supports critical discussions of the criteria for evaluating the rigor and effectiveness of new media that reflect the broadened perspective on practice.

The critical issues of quality new media, the identification of qualifications and develop international policies for globalization can merge the interests of international public goods, the higher education sectors, the needs of digital citizens and the worldwide public interest. Because today's world is complex and knowledge is developing fast, learning must go on throughout life. Not only online adults but also digital youth should know how to deal with change that requires reformist actions in the quality of online organizations in all its aspects to accomplish excellence in communication. Identifying the issues, challenges, priorities and needs of online communities for knowledge management develops to prioritize the goals and major issues to enhance the relevance of communication by adjusting collaboration processes, multicultural contents and egalitarian knowledge management to embrace online organizations and their qualities (Kyrish, 2004). The major challenges of global online culture focus on global democratic citizenships, respect online human rights and social identities by measuring how to build accountable knowledge management systems under a framework with suitable capacity-building to make critical decisions and construct powerful action plans. On the other hand, the major priorities of culture cam underline the necessary improvements, and promoting intellectual and scientific collaborations of online organizations that empower knowledge managements with regard to considering the global societal values. In addition, the major needs to utilize the advantages and potential of advanced communication technologies by guaranteeing quality and sustaining high standards for practices and outcomes ensure online facilities based on local, national and global networks, and increase online organizations efficiency as well as preserve their quality and significance. There are efforts around the globe to reform culture, progressively considered as a critical action for being digital citizens to improve equity of access and opportunity, and strengthen communication milieus (Fisher \& Wright, 2001). Knowledge obtained in setting can have suggestions for policy and practice in networked society, and researchers and policymakers increasingly recognize the importance of comparative perspectives on organization culture. There is an urgent need to plan and conduct new media developments in a systematic approach that includes identifying needs, selecting the best strategies from among known options, monitoring changes as they occur, and measuring the influence of these changes. 
Assessing the quality of online society culture, therefore, can provide digital citizens with an agenda as a communication process to answer various problems, dilemmas and obstacles about a wide variety of culture. Furthermore, this involves digital citizens in activist change actions to focus on authentic experiences in critical dialogues. There exists a common consensus on the authenticity of advancing new media that promotes new critical approaches in organization culture. These online societies should give urgent priority to dealing with research measuring quality, increasing the relevance of online communication, quality for digital citizens, reforming the online communication system, and better collaboration systems. The credibility, viability and quality of either current or prospective global online culture provide fundamental inquires for critical reflections. A better understanding and measurement of quality of global online culture in the diverse contexts of new media provides disadvantage individuals with quality opportunities to address these citizens' needs as well. As mentioned by Picciano (2002), global online culture makes sure that new media presents ideas and values about building a sustainable future, give digital citizens the chance and learn about the global world. This can be build indepth respect for diversity and differences. Rethinking global online culture by focusing on the more pressing social and societal problems of our time, and also understands the achievement challenges and assessment concerns of lifelong learning (Stevens-Long \& Crowell, 2002; Worthen \& Sanders, 1987). Finally, new media provide digital citizens with pedagogical knowledge for the global online culture-oriented design in a multicultural view that these people gain a better understanding of how people of different cultures behave in the online world - their behavior, appearance and communication performances.

\section{Conclusion}

The main purpose of this study is to discuss how culture affects new media to empower online communications to build democratic digital societies. Like the use of traditional media, new media, therefore, are strongly related to the design models and strategies of constructing global online culture (Salmon, 2002; Torres, 1998; Williams, 2003). Therefore, digital citizens carefully redesign and revolutionize their new roles in online milieus together. These people should learn how to discover new communication technologies and their relationships to societal and educational change; focus on working collaboratively with each other regularly to promote excellence through continuous process improvement and the creative pursuit of new ideas and systems; plan, manage and lead effectively in professional development and life-long learning endeavors to construct knowledge networks, and investigate the relationship between culture and new media to build democratic and multicultural knowledge networks. Building global culture through new media can help digital citizens actively engage in their communication progresses. This process, also, helps these people to effectively transfer their knowledge to new contexts. As a result, online participants can improve their complex critical thinking skills to create, produce or demonstrate their knowledge. Moreover, digital citizens can involve innovation in assessment to meet their changing needs and to realize new opportunities for sharing knowledge online. As discussed by Stephenson (2001), and Yang and Cornelious (2005), online societies, a type of micro-society where digital citizens work and live together on a daily basis, with certain rules and understandings about what is acceptable and what is not. The idea of an online community having a culture developed from the work of Hofstede on national cultures must focus on multicultural approaches of understanding global culture in different contexts. 


\section{References}

Abbey, B. (2000). Instructional and Cognitive Impacts of Web-Based Education. Hershey, PA: Idea.

Bates, A. W. (2000). Managing Technological Change. San Francisco, CA: Jossey-Bass.

Berg, G. A. (2000). "Early Patterns of Faculty Compensation for Developing and Teaching Distance Learning Courses", The Journal of Asynchronous Learning Networks (JALN), 4(1) Retrieved May 26, 2001, from http://www.aln.org/alnweb/journal/jaln-vol4

Beaudoin, M. F. (2003). "Distance Education Leadership for the New Century", Online Journal of Distance Learning Administration, 6(2). Retrieved November 11, 2004, from: http://www.westga.edu/\%7Edistance/ojdla/summer62/beaudoin62.html

Bolliger, D. U. \& Martindale, T. (2004). "Key Factors For Determining Student Satisfaction in Online Courses", International Journal on E-Learning, 3(1), 61-67.

Brosio, R. A. (1994). A Radical Democratic Critique of Capitalist Education. New York, NY: Peter Lang.

Burge, L. (2000). The Strategic Use of Learning Technologies. San Francisco, CA: JosseyBass.

Burke, K. \& Chidambaram, L. (1999). "How Much Bandwidth is Enough? A Longitudinal Examination of Media Characteristics and Group Outcomes", MIS Quarterly, 23(4), 557580.

Burniske, R. W. \& Monke, L. (2001). Breaking Down the Digital Walls: Learning to Teach in a Post-Modem World. Albany, NY: State University of New York Press.

Chua, A. \& Ngee A. P. (2001). "Relationship between the Types of Knowledge Shared and Types of Communication Channels Used", Journal of Knowledge Management Practice, Retrieved May 23, 2002, from: http://www.tlainc.com/articl26.htm

Culwin, F., MacLeod, A. \& Lancaster, T. (2001). "Source Code Cyber-Democracy in UK HE Computing Schools, Issues, Attitudes and Tools", South Bank University Technical Report SBU-CISM-01-02.

Fabos, B. \& Young, M. D. (1999). "Telecommunication in the Classroom: Rhetoric versus Reality", Review of Educational Research, 69(3), 217-259.

Fisher, D. R. \& Wright, L. M. (2001). "On Utopias and Dystopias: Toward an Understanding of the Discourse Surrounding the Internet", Journal of Computer-Mediated Communication, 6(2), 13. Retrieved July 02, 2002, from: htpp://www.ascusc.org/jcmc/vol6/issue2/fisher.html

Hodson, D. (1999). "Critical Multiculturalism in Science and Technology Education", In S. May (ed.) Critical Multiculturalism: Rethinking Multicultural and Antiracist Education (pp. 216-244), Philadelphia, PA: Falmer.

Howell, S. L., William, P. B. \& Lindsay, N. K. (2003). "Thirty-Two Trends Affecting Distance Education: An Informed Foundation for Strategic Planning", Online Journal of Distance Learning Administration, 6(3). Retrieved June 25, 2006, from:

http://www.westga.edu/ distance/ojdla/fall63/howell63.html

Hofstede, G. J., Pedersen, P. B. \& Hofstede, G. (2002). Exploring Culture: Exercises, Stories, and Synthetic Cultures. Yarmouth, ME: Intercultrual.

Huerta, E. Ryan, T. \& Igbaria, M. (2003). "A Comprehensive Web-Based Learning Framework: toward Theoretical Diversity", In A. Aggarwarl (ed.) Web-Based Education: Learning from Experiences (pp. 24-35). Hershey, PA: Information System.

Kendall, L. (2003). Cyberculture. In S. Jones (ed), Encyclopedia of New Media (pp. 102-104). New York, NY: Sage.

Kyrish, S. (2004). "Creating an Online Program", In D. Momolescu, C. C. Schifter \& L. Greenwood (eds.) The Distance Education Evaluation: Issues and Case Studies (pp. 1-21). Hershey, PA: Information Science.

Lorenz, E.N. (1972). "Barotropic Instability of Rossby Wave Motion", Journal of Atmosphere Sciences, 29, 258-264.

Mamadouh, V. D. (1997). "Political Culture: A Typology Grounded on Cultural Theory", GeoJournal, 43(1), 17-25. 
May, S. (1999). "Introduction: Towards Critical Multiculturalism", In S. May (ed.) Critical Multiculturalism: Rethinking Multicultural and Antiracist Education (pp. 1-10). Philadelphia, PA: Falmer.

McChesney, R. W. (1999). Rich Media, Poor Democracy: Communication Politics in Dubious Times. Urbana Champaign IL: University of Illinois.

Moore, M. \& Kearsley, G. (2005). Distance Education: System View. Belmont, CA: Thomson Wadsworth.

Moore, P. E. \& Tait, A. (Eds.) (2002). Open and Distance Learning: Trends, Policy and Strategy Considerations. Paris: UNESCO.

Neo, M. (2005). "Web-Enhanced Learning: Engaging Students in Constructivist Learning", Campus Wide Information Systems, 22(1), 4-14.

Nieto, S. (1996) Affirming Diversity: The Social Context of Multicultural Education. White Plains, NY: Longman.

Picciano, A. G. (2002). Educational Leadership and Planning for Technology (3 ${ }^{\text {rd }}$ ed.). Columbus, OH: Upper Saddle River.

Porter, L. R. (2004). Developing an Online Curriculum: Technologies and Techniques. Hershey, PA: Information System.

Powazek, D. (2002). "Design for Community: The Art of Connecting Real People in Virtual Places", Philosophical Perspectives on Constructivist Views of Learning, 29(1), 37-48.

Preece, J., Rogers, Y. \& Sharp, H. (2002). Interaction Design. New York, NY: John Wiley \& Sons.

Resta, P. (ed.) (2002). Information and Communication Technologies in Teacher Education: A Planning Guide. Paris: UNESCO.

Rosenberg, M. J. (2001). E-Learning: Strategies for Delivering Knowledge in the Digital Age. Washington, DC: McGraw-Hill.

Schrum, L. \& Benson, A. (2002). "Establishing Successful Online Distance Learning Environments: Distinguishing Factors that Contribute to Online Courses and Programs", In R. Discenza, C. Howard \& K .Schenk (eds.) The Design \& Management Effective Distance Learning Programs (pp. 190-204). Hershey, PA: Idea.

Sheets, R. H. (2005). Diversity Pedagogy: Examining Role of Culture in Teaching-Learning Process. New York, NY: Pearson.

Spring, J. (1999). Wheels in the Head: Educational Philosophies of Authority, Freedom, and Culture from Socrates to Human Rights. Madison, WI: McGrawHill.

Stevens-Long, J. \& Crowell, C. (2002). "The Design and Delivery of Interactive Online Graduate Education", In K. E. Rudestam \& J. Schoenholtz-Read (eds.) Handbook of Online Learning: Innovations Higher Education and Corporate Training (pp. 151-169). Thousand Oaks, PA.

Torres, C. A. (1998). Democracy, Education, and Multiculturalism: Dilemmas of Citizenships in a Global World. Lanham, MD: Rowman \& Littlefield.

Salmon, G. (2000). E-Moderation: The Key Teaching and Learning Online. London: Kogan Page.

Salmon, G. (2002). E-Tivities: The Key to Active Online Learning. London: Kogan Page.

Scardamalia, M. (2003). "Crossing the Digital Divide: Literacy as By-Product of Knowledge Building", Journal of Distance Education, 17, 78-81.

Stephenson, J. (Ed) (2001). Teaching and Learning Online: Pedagogies for New Technologies. London: Kogan Page.

Williams, P. E. (2003). "Roles and Competencies for Distance Education Programs in Higher Education Institutions", the American Journal of Distance Education, 17(1), 45-57.

Worthen, B. R., \& Sanders, J. S. (1987). Educational Evaluation: Alternative Approaches and Practical Guidelines. White Plains, NY: Pitman.

Yang, Y., \& Cornelious, L. F. (2005). "Preparing Instructors for Quality Online Instruction", Online Journal of Distance Learning Administration, 8(1). Retrieved October 08, 2005, from

http://www.westga.edu/ distance/ojdla/spring81/yang81.htm 